\title{
OS NÍVEIS DE ALFABETIZAÇÃO EM SALA DE AULA, NA CONCEPÇÃO DE EMÍLIA FERREIRO
}

\section{THE LEVELS OF LITERACY IN A CLASSROOM, IN THE CONCEPTION OF EMÍLIA FERREIRO}

\author{
Tatiane Maciel Beza ${ }^{1}$ \\ Samira Casagrande ${ }^{2}$
}

\begin{abstract}
RESUMO: O artigo apresentado busca compreender a prática dos professores do primeiro ano do ensino fundamental, quanto a utilização dos diferentes níveis de escrita segundo a psicogênese de Emília Ferreiro para avaliar o processo inicial de alfabetização. Desta forma, ocorreu uma pesquisa teórica, baseada em diversos autores, para posteriormente ocorrer uma entrevista semiestruturada com sete professores da rede municipal do Extremo Norte do Rio Grande do Sul. A entrevista teve como objetivo o reconhecimento das professoras sobre os níveis da psicogênese dentro da sala de aula, se este conhecimento existia na grade curricular de suas formações iniciais e também um questionamento quanto aos diferentes métodos de ensino existentes para o processo de alfabetização. É nítido durante a análise realizada, que os professores entrevistados ainda baseiam-se num ensino tradicional e mecanicista, mesmo afirmando algumas vezes conhecer e praticar um ensino construtivista, ainda relatam práticas como a utilização das famílias silábicas, de ensino baseado em estímulo e resposta, e muitas vezes sem mencionar qualquer base teórica para a realização de suas atividades práticas, ou seja, uma alfabetização que ocorre a partir daquilo que o professor acredita ser necessário e estar correto.
\end{abstract}

PALAVRAS CHAVE: Psicogênese da Língua Escrita; Métodos de Alfabetização; Formação Inicial Docente.

ABSTRACT: This article aims to understand the practice of first year teachers of elementary school regarding the use of different levels of writing according to the psychogenesis of Emília Ferreiro to evaluate the initial literacy process. In this way, a theoretical research was carried out, based on several authors, and later a semi-structured interview with seven teachers of the municipal network of the Extreme North of Rio Grande do Sul was made. The objective of the interview was the recognition of the teachers about the levels of psychogenesis within the classroom, if this knowledge existed in the curriculum of their initial formations and also to question about the different teaching methods that exist for the literacy process. It is clear during the analysis that the teachers interviewed are still based on a

\footnotetext{
${ }^{1}$ Graduanda em Pedagogia/ UNESC. sca@unesc.net

2 Graduada em Pedagogia. Mestre em Educação. sca@unesc.net

Saberes Pedagógicos, Criciúma, v. 3, nº1, janeiro/junho 2019.-Curso de Pedagogia- UNESC
} 


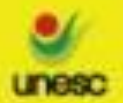

This nuiges

unesc

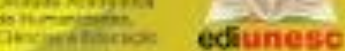

traditional and mechanistic teaching, even stating that they sometimes know and practice constructivist teaching, they still report practices such as the use of syllabic families, teaching based on stimulation and response, and often without mentioning any theoretical basis for carrying out their practical activities, that is, a literacy that occurs from what the teacher believes to be necessary and correct.

KEYWORDS: Psychogenesis of the Written Language; Literacy Methods; Initial Teacher Training.

\section{INTRODUÇÃO}

A escolha do tema do artigo apresentado se deu a partir da disciplina de Processos Pedagógico da Alfabetização e Letramento, do Curso de Pedagogia da UNESC, que acarretou uma grande curiosidade diante dos diferentes níveis de alfabetização existentes durante o processo de aprendizagem de leitura e escrita. Curiosidade esta que ganhou forças a partir das experiências nos estágios obrigatórios, durante as observações e regências, onde foi possível perceber essa diferença existente e o quanto as professoras de alfabetização ignoram o ensino psicogenético.

Durante muito tempo foi visto a prática pedagógica ser baseada em uma educação tradicional, em que a criança era vista como um mero receptor, sendo assim, ia-se para a sala de aula apenas para decorar as letras e/ou palavras, decodificadas, sem que existisse qualquer reflexão com a realidade social. Também, a interpretação da escrita era tratada como algo de segundo plano, ou seja, somente quando "todos já soubessem tudo" é que se tornaria possível o aluno saber refletir sobre aquilo que escreveu. Era ignorado o caminho que o aluno percorria para a compreensão da leitura e escrita, justificando a "demora" deste processo, por conta dos métodos que são utilizados em sala de aula.

A partir disto, o artigo foi desenvolvido com referencial teórico baseado em Braggio (1992), Ferreiro e Teberosky (1999), Gil (1996), Gontijo (2014), Libâneo (2001), Moita (2000), Mortatti (2000), Nóvoa (1992), Oliveira (2002), Pimenta e Gonçalves (1990), Smolka (1999) e Soares (2005), proporcionando o conhecimento sobre o uso da psicogênese na alfabetização, os diferentes métodos de ensino de alfabetização existentes e o processo de formação inicial dos professores. Fazendo-se necessária uma reflexão sobre como estas teorias estão sendo apresentadas em sala de aula e de que forma estão sendo trabalhadas.

Saberes Pedagógicos, Criciúma, v. 3, nº1, janeiro/junho 2019.- Curso de Pedagogia- UNESC 


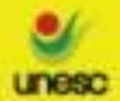

Para isto foi utilizado uma pesquisa de natureza qualitativa exploratória, realizada através de coleta de dados por meio de uma pesquisa com roteiro, que contou com perguntas abertas numa entrevista semiestruturada, realizada com sete professoras da rede municipal do extremo norte do Rio grande do Sul. A análise de dados ocorreu posteriormente, oportunizando a reflexão entre a teoria apresentada no referencial e a prática relatada pelas professoras entrevistadas.

\section{MÉTODOS DE ENSINO PARA A ALFABETIZAÇÃO}

Segundo Gontijo (2014) a alfabetização brasileira passou por diversas mudanças nos últimos anos e isto inclui os métodos de ensino utilizados dentro da sala de aula, que historicamente são adquiridos nas escolas com intuito de se encontrar o meio ideal de ensino. Para isto, Gontijo (2014) discute a teoria defendida por Ferreiro, Teberosky (1999) sobre o processo de desenvolvimento da escrita e a ação pedagógica diante as diferentes situações de sala de aula. A partir disto, é válido lembrar que "o fracasso escolar é um problema antigo. E antiga também é a tendência daqueles que determinam os rumos da educação, que atribuem à escola e à formação dos professores a responsabilidade por esse fracasso. " (2014, p. 68). Portanto, buscar novos métodos de ensino não necessariamente é o que soluciona esse desfalque existente na alfabetização.

Com base em Soares (2005) a primeira questão importante é identificar o que se entende por métodos. Neste caso, é necessário dividi-la em duas questões, primeiramente, o fato de que o fracasso escolar está constantemente justificado pelos métodos que são utilizados, evidenciando neste caso, o uso dos métodos tradicionais. Em segundo lugar, complementando a primeira situação, quando se utiliza o termo método na educação, ele é ligado diretamente com os tipos tradicionais de métodos (fônico, silábico, global etc.), "como se esses tipos esgotassem todas as alternativas metodológicas na aprendizagem da leitura e da escrita [...]. ” (SOARES, 2005, p.93). Impossibilitando a inclusão de qualquer outro método pedagógico.

Ferreiro e Teberosky, (1999) e Mortatti (2000) também discutem a questão do método milagroso, ou seja, um método capaz de solucionar os problemas identificados no 


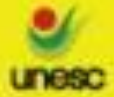

processo de desenvolvimento da leitura e escrita, tendo como foco as diferenças decorrentes entre o analítico e o sintético. Sendo que, os métodos sintéticos são aqueles que iniciam a escrita através de elementos mínimos de uma palavra, enquanto que os métodos analíticos partem de uma parcela maior, ou seja, através de palavras e/ou orações. Sendo assim, o método sintético, defende que a criança primeiramente precisa compreender o oral, começando essa alfabetização com fonemas que não dificultem nem modifiquem a escrita, fonemas simples. Depois que a criança identificar as letras pelo som que cada uma representa, ai sim, ela está apta para iniciar a escrita convencional do que se fala. Deste modo é um meio de padronização da linguagem oral.

Posteriormente, para Mortatti (2000) o método analítico aparece por meio de uma reforma no ensino brasileiro, que se caracterizou por uma adesão de cartilhas. Primeiramente a Martilha Maternal ou Arte da Leitura criada em Portugal que trazia o método João de Deus, e buscava ensinar a leitura-escrita a partir da palavra, para somente depois buscar o significado sonoro. Deste modo, o método analítico acaba por acusar o método sintético de "mecanicista" e defender que, o processo de escrita se dá através do visual. Portanto, o grafema prevalece o fonema. Ou seja, é adquirido a escrita através da visualização de palavras, orações, contextos, que induzam a criança a identificar quais letras estão sendo utilizadas. Não necessariamente, ressaltando o valor sonoro de cada letra e suas diferentes representações. Entretanto, deve-se buscar sempre o simbólico, aquilo que tem sentido conforme a realidade da criança, ou seja, o ideal para se vê/lê (MORTATTI, 2000).

Neste momento, Braggio (1992) vem discutir a teoria bloomfieldiano, que parte do princípio de que a aquisição da escrita se dá através de uma repetição dos sons, e que essa experiência deve começar dos "fonemas fáceis" para posteriormente incluir os mais complexos, o que Braggio (1992, p.11) vai chamar de "controle de aprendizagem", ou seja, a professora determina em que momento se torna apropriado a criança aprender novas letras e quais destas serão escolhidas. Deixando evidente que o ensino não busca o significativo para a criança, pois isto será adquirido depois que a criança já possuir total domínio de escrita. Tradicionalmente é posto que as palavras devem ser escritas da esquerda para a direita e lidas da mesma maneira, não aceitando qualquer outro meio de escrita que a criança tente 

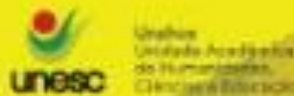

desenvolver. Automaticamente, não são aceitos erros, pois os mesmos, são vistos como malefícios para esta aprendizagem de escrita.

A partir disto, Gontijo (2014) apresenta sua teoria deixando em evidencia o construtivismo, que vai contra, segundo a prática pedagógica atual, os métodos tradicionais. Sendo assim, busca compreender o desenvolvimento da leitura e escrita, segundo a teoria da psicogênese de Ferreiro e Teberosky (1999) que deixa evidente que o olhar pedagógico precisa mudar, pois a criança deixou de ser um mero receptor e passou a ter voz e ação dentro da sala de aula, buscando refletir sobre a escrita e o modo como faz sua aquisição. Sendo assim, a criança parte de hipóteses, que cria através de suas experiências e tentativas de escritas, valorizando todos os processos.

Portanto, a criança desenvolve sua escrita a partir de suas próprias descobertas. Neste momento a psicogênese de Emília Ferreiro torna-se um marco para a alfabetização, pois complementa este processo de descoberta das crianças e exalta a importância da observação dos professores diante este processo, desfazendo-se da prática de ignorar os erros. Isto é, fica evidente a importância de observar todo o processo de desenvolvimento da criança e não somente aquilo que deu certo.

\subsection{PSICOGÊNESE DA LÍNGUA ESCRITA: UMA TEORIA A SER CONTADA}

Segundo Ferreiro e Teberosky (1999, p.24) atualmente, nas instituições escolares, não nos deparamos mais com crianças passivas, que estão esperando o adulto lhe mostrar exatamente o que e como fazer. Mas sim crianças capazes de refletir, de construir conhecimento e de "criar hipóteses", colocando em prática sua própria escrita gráfica, a partir de todo estudo e entendimento que ela faz por si só, "que não é simples cópia deformada do modelo adulto, mas sim criação original. " (FERREIRO, TEBEROSKY, 1999, p.24).

Sendo assim, Ferreiro e Teberosky dizem que, "o que antes aparecia como um 'erro por falta de conhecimento' surge-nos agora como uma das provas mais tangíveis do surpreendente grau de conhecimento que uma criança dessa idade tem sobre seu idioma [...]" (FERREIRO, TEBEROSKY, 1999, p.25). Atualmente, tornou-se possível entender este "erro" como algo produtivo. Ou seja, a criança cria sozinha sua lógica na escrita, de forma

Saberes Pedagógicos, Criciúma, v. 3, nº1, janeiro/junho 2019.- Curso de Pedagogia- UNESC 


\section{SABERES PEDAGÓGICOS}

Revista do Curso de Graduaçāo de Pedagogia - Unesc

ISSN $2526-4559$

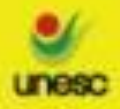

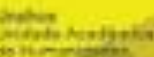

edineso

que consiga se fazer entender e com um nível de lógica muito mais eficaz do que o modelo da escola. Mas normalmente, nesses casos, o professor, por não saber ou não ter uma lógica suficientemente boa para desconstruir o pensamento da criança, opta por acusar a criança deste "erro", para que desta forma, consiga esconder a sua própria inabilidade.

A análise feita por Ferreiro e Teberosky (1999) sobre o processo de construção da escrita, diz que ao recebermos as crianças, não podemos considerar que elas não sabem nada sobre sua língua materna. “[...]. Não se trata de transmitir um conhecimento que o sujeito não teria fora desse ato de transmissão, mas sim de fazer-lhe cobrar a consciência de um conhecimento que o mesmo possui, mas sem ser consciente de possuí-lo. [...].” (FERREIRO, TEBEROSKY, 1999, p.27). A psicogênese traz que ensinar a ler-escrever, não é um ato que se começa do "zero", pois o sujeito, já tem um conhecimento da linguagem escrita e já realiza uma distinção verbal, mesmo que sem perceber. Portanto, a ação neste caso, é fazer com que a criança descubra essa capacidade que já possui e não introduzir "tudo novo".

A partir disto, Smolka (1999) alerta sobre a visão equivocada que se cria ao defender esta prática, pois o modelo que se adquiriu nas escolas é baseado em uma rejeição da conversa crítica, a ideia errônea de que o que se entende e se conhece fora do ambiente escolar, ou o que se discute em conversas não pode ser considerado como algo que contribua para a alfabetização. Alimentando dessa forma uma alfabetização egocêntrica, logo uma compreensão equivocada da "autonomia dos alunos". Pois atualmente, muito se vê que, “autônomo' é aquele que 'entende' o que a professora diz; aquele que realiza sozinho, as tarefas; é aquele que 'não precisa perguntar'; é aquele que 'não precisa dos outros." (SMOLKA, 1999, p.50). Ou seja, cria-se a ilusão da "autossuficiência", e mais do que isto, classifica os demais como "fracassados ou incapazes".

Por consequência "[...] supõem-se e conclui-se que: as crianças têm problemas; que elas são incapazes; que elas não prestam atenção e não têm os pré-requisitos desenvolvidos; consequentemente, não podem ser alfabetizadas. " (SMOLKA, 1999, p.39). Assim, revela-se um ciclo vicioso, de que esses alunos "fracassados ou incapazes" não são responsabilidade do professor, pois o fato de não aprenderem é justificado por suas prováveis perturbações. Portanto, procura-se o apoio profissional psicológico existente nas escolas para sustentar/justificar o pensamento do professor para com esses alunos, o que acaba 

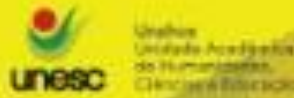

phomingen

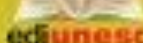

contribuindo para esta (des) classificação existente em sala de aula. Ou seja, "configura-se, assim, as condições de produção de repetência e da evasão escolar, legitimada pelo "conhecimento cientifico (testes) da psicologia atual". (SMOLKA, 1999, p. 37). Deste modo, não será necessário mudar sua visão sobre os meios de ensino para esses alunos "fracassados" pois os que não possuem essas perturbações são capazes de aprender. Sendo assim, cria-se um modelo ideal de aluno, isto é, aquela criança que tudo entende, de acordo com o que a professora espera. Entretanto, Ferreiro (1999) mostra que o papel da criança na alfabetização passou por mudanças significativas, que proporcionaram um novo olhar para as crianças como "sujeitos ativos" e não mais como meros receptor de novas ideias. Por conta disto, a autora juntamente com Ana Teberosky apresenta a teoria da psicogênese, baseada nos estudos de Piaget e sua concepção construtivista, ou seja, o processo de desenvolvimento da aprendizagem da escrita.

Para isto, Ferreiro e Teberosky (1999) apresentam quatro níveis de hipóteses de escrita em que as crianças passam durante o desenvolvimento da alfabetização, para assim "revelar os processos de aquisição do pensamento". Dentro destas hipóteses, a primeira é denominada como pré-silábica, e se subdivide em dois níveis, sendo o primeiro nível o que a criança não estabelece vínculo entre a fala e a escrita, onde normalmente esta escrita é realizada por meio de garatujas, e o segundo nível é aquele que ocorre quando a criança já faz conhecimento da grafia, diferenciando letras de imagens e números. Porém, esta diferenciação se dá em determinadas situações. Ou seja, uma letra sozinha pode ser identificada como número, (por exemplo, a letra E, sozinha, poderá ser classificado como o número 3) e as explicações para esta escolha são desde que ela sozinha não pode ser lida até pela semelhança que existe entre ambas. Sendo assim "[...] para as crianças, o problema surge de outra maneira: a mesma forma gráfica pode ser uma coisa ou outra em função do contexto. Para que algo seja uma letra, é preciso que esteja com outras letras. [...].” (FERREIRO, TEBEROSKY, 1999, p.47). Para as crianças, apenas uma letra não é algo que pode ser lido, pois ali não diz nada. As letras sozinhas (e em muitos casos com duas) não são para ler, não possuem utilidade. No entanto, ao acrescentar mais, essas mesmas letras classificadas como "ilegíveis" tornam-se "legíveis". Ou seja, o que diferencia a letra do número é o seu contexto. Sendo que, um número sozinho, já é o suficiente para determinar uma quantidade desejada.

Saberes Pedagógicos, Criciúma, v. 3, nº1, janeiro/junho 2019.- Curso de Pedagogia- UNESC 


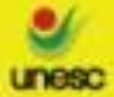

Mas, quando se refere a escrita, ainda dentro desta hipótese, segundo as autoras citadas, ela ocorre através de regras definidas pela própria criança, tendo na maioria das vezes a utilização do seu próprio nome como referência de letras. Outra característica desta hipótese, é a definição de quantidade mínima que uma palavra pode ter para ser lida. Sendo que na concepção das crianças, normalmente, essa escrita é aceitável com uma quantidade mínima de três letras, confirmando aquilo que as autoras nomeiam de "intrafigural". Após identificar essa quantidade mínima, as crianças procuram exigir uma variedade de caracteres, ação esta que é caracterizada pela prática interfigural, ou seja, a necessidade de uma qualidade na escrita. Portanto, uma palavra não pode ser escrita com uma sequência de uma única letra ou ainda, duas palavras diferentes não podem ser escritas de uma mesma maneira. Ainda dentro desta hipótese, segundo Soares (2005), encontra-se a escrita icônica, onde a criança utiliza-se de desenhos para representar aquilo que deseja escrever. E a não icônica, em que a criança abandona o desenho e passa a imitar em suas representações a escrita com que está acostumada a presenciar, realizando diversas tentativas de imitação do seu jeito.

A segunda hipótese em que a criança se encontra é a silábica, que determina o momento em que a criança supõe que a escrita representa a fala, percebendo, portanto, que as palavras possuem sons segmentados, passando a identificar a separação das sílabas no momento da escrita, sendo assim "a hipótese silábica é uma construção original da criança, que não pode ser atribuída a uma transmissão por parte do adulto. [...]." (FERREIRO, TEBEROSKY, 1999, p.213). Ainda, esta hipótese também está dividida em dois níveis, primeiramente a escrita sem valor sonoro, que ocorre quando a criança utiliza uma letra para representar cada sílaba, sendo que esta escolha não necessita estar conciliada com um significado sonoro da palavra. Porém, no segundo nível dentro desta hipótese, a criança utiliza a mesma prática de uma letra para representar cada sílaba, mas com um significado sonoro, baseando-se normalmente nas vogais em que apresentam mais ênfase dentro da palavra.

Segundo Ferreiro e Teberosky (1999) a prática nas escolas se consolida a partir da ideia de que palavras como "mamãe, papai" deveriam ser trabalhadas primeiro, pois são fáceis de serem interpretadas pelas crianças. Entretanto, o que a psicogênese mostra é justamente o contrário deste pensamento, pois ao receber uma palavra com letras iguais, repetidas, ou com poucas (considerando a lógica intrafigural que a criança adota) é possível perceber que está

Saberes Pedagógicos, Criciúma, v. 3, nº1, janeiro/junho 2019.- Curso de Pedagogia- UNESC 


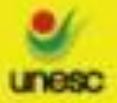

Thisiones

unese

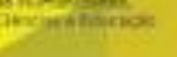

sendo dificultado este processo para a criança, pois não lhe é perguntado sobre essa "facilidade" nem tão pouco preocupa-se com isto. "[...]. Essas palavras iniciais são precisamente as primeiras, porque são consideradas como fáceis: por serem curtas e por representarem os mesmos grafismos repetidos. [...]. Fáceis para quem? Fáceis desde que ponto de vista, desde qual definição de qualidade? " (FERREIRO, TEBEROSKY, 1999, p.67). O que as autoras ressaltam aqui é justamente uma reflexão sobre esta prática. Pois do ponto de vista da psicogênese a escrita com poucas e/ou grafias iguais, é justamente o que as crianças classificam como "impróprias" para ler. Smolka (1999, p.48) vem defender este mesmo pensamento, mostrando que a professora cria sua teoria de como as crianças desenvolvem a leitura e a escrita, acreditando que ao utilizar, por exemplo, a frase "a pata nada" como referência, ela está ajudando, pela semelhança existente entre as palavras/letras. Baseando, além disso, sua escrita completamente em repetição e fixação de imagens como reforço para o desenvolvimento da criança.

A terceira hipótese apresentada por Ferreiro e Teberosky é denominada silábica alfabética, e ocorre quando a criança percebe que faltam letras nas suas palavras escritas, assim sendo "[...] a criança abandona a hipótese silábica e descobre a necessidade de fazer uma análise que vá 'mais além' da sílaba pelo conflito entre a silábica e a exigência de quantidade mínima de grafias [...]" (FERREIRO, TEBEROSKY, 1999, p.214). Ou seja, é um momento de transição entre a hipótese silábica e a alfabética, sendo que ora a criança utilizase de uma escrita baseada por valores sonoros - uma letra por sílaba - ora a criança representa está escrita por meio da grafia convencional.

A última hipótese apresentada por Ferreiro e Teberosky (1999) é a alfabética, que é o nível em que a criança já compreendeu o sistema de escrita. Neste momento a criança domina o fato de que cada letra monta uma sílaba que se forma em uma palavra, explorando corretamente a escrita. Entretanto pode ou não dominar as "convenções ortográficas", sendo assim " $[. .$.$] a criança se defrontará com as dificuldades próprias da ortografia, mas não terá$ problemas com a escrita, no sentido escrito. " (FERREIRO, TEBEROSKY, 1999, p.219). Portanto, já reproduz corretamente os fonemas e consegue distinguir letras, sílabas, palavras e frases, mas ainda pode ocorrer algum erro ortográfico, na grande maioria causado pela aparência do som de cada letra, como S/SS, X/CH.

Saberes Pedagógicos, Criciúma, v. 3, nº1, janeiro/junho 2019.- Curso de Pedagogia- UNESC 
Neste momento, Ferreiro e Teberosky (1999) ressaltam a importância de diferenciar as dificuldades existentes quanto a escrita e quanto a ortografia, pois, as crianças quando chegam nesta hipótese já compreendem que existe uma forma convencional de escrita, mas também que se algo for escrito de uma outra forma não iria prejudicar a escrita, porque ainda assim estaria se referindo a mesma coisa. Deixam evidente que o erro acontecerá não por não saber escrever, mas por uma falta de habilidade ortográfica que será desenvolvida com o tempo e a prática.

\subsection{O PROCESSO DA FORMAÇÃO INICIAL DE PROFESSORES}

Segundo Gontijo (2014) a educação no Brasil passou por melhorias no ano de 2005, quando o MEC integrou o Sistema Nacional de Formação de Professores no Plano Nacional de Qualidade para a Educação Básica. No entanto, existiu diferentes etapas até chegar a esta prática.

Para Pimenta e Gonçalves (1990) a formação de professores passou por diversas transformações, mas, até o ano de 1970 esses atos serviram somente para piorar essas formações. Ou seja, a prática vazia de conteúdo, não consolida a prática necessária para uma formação geral, nem tampouco para uma formação pedagógica perdurável. Do mesmo modo que a "área" que deveria fundamentar a educação, acaba por ser supérflua, pois não fundamenta os aspectos essenciais do ensino, sendo eles "os aspectos sociológicos, históricos, filosóficos e psicológicos da educação. ” (PIMENTA, GONÇALVES, 1990, p.92). Além disso, a prática na formação profissional não ocorria de acordo com a realidade das escolas.

Segundo Pimenta e Gonçalves (1990) a formação do professor passou por diversas mudanças dos anos 30 aos anos 70. Entretanto, esta formação se deu desde 1833, onde criouse a Escola Normal de Niterói-RJ, e outras tantas decorrentes dessa. Apesar de essa Escola surgir em um momento importante, (para contrariar o governo atual), ela ainda era classificatória, portanto "[...] a escola normal era, nesse início, destinada exclusivamente aos homens, uma vez que o papel da mulher se resumia às lidas do lar. " (PIMENTA, CONÇALVES, 1990, p. 97). Esta prática perdurou até o século XX, momento em que as mulheres ganham acesso a "escola normal". Gradativamente este ensino evolui, no entanto 

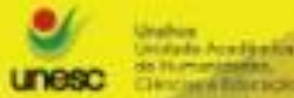

muito longe do que se espera como modelo. A partir do ano de 1930, o país começa a desenvolver a indústria agrícola muito rápido, o que acaba por exigir uma demanda maior de funcionários que saibam lidar com as máquinas. Neste caso, o governo se obriga a “organizar" a educação, o que resultará na criação das "Leis Orgânicas do Ensino (1942 a 1946) ". Esse processo chega ao ápice na década de 60, tornando a educação coadjuvante, fundamental, mas ainda não prioritária.

A partir disto, a população ciente dos benefícios da escolarização, toma voz e requer mais escolas, no mesmo momento em que a organização da educação passa por mudanças, tendo como princípio as "diretrizes e normas de caráter nacional" (PIMENTA, GONÇALVES, 1990, p.98). Tal ação do governo, tem como propósito parar as pessoas que buscam ações sociais através de novas escolas, fortalecendo seu poder e sua ação individualista. Um último fator relevante neste período, que as autoras apresentam, foi a Segunda Guerra Mundial, pois até então os profissionais existentes no Brasil, eram importados. Entretanto, neste momento por conta da queda da economia o país se obrigou a formar seus próprios profissionais. Surge, portanto, em 1934, a primeira Universidade brasileira (USP) e o primeiro curso de formação em Pedagogia surgem logo após, em 1939. Percebe-se que historicamente a formação de professores se dá através de uma necessidade política, econômica e social. Neste momento, o processo de formação de professores ocorria em dois ciclos. "Primeiro ciclo, destinado à formação de regentes de ensino primário; com a duração de quatro anos, funcionava nas chamadas 'escolas normais regionais'." (PIMENTA, GONÇALVES, 1990, p.99). Enquanto que o "segundo ciclo, com finalidade de formar professores primários. Funcionava em 'escolas normais' e tinham a duração de três anos. " (PIMENTA, GONÇALVES, 1990, p.99). Além dessas duas ações já mencionadas, a Lei Orgânica preocupava-se em formar especialistas em todas as áreas existentes e necessárias dentro do ambiente escolar, sejam eles docentes ou técnicos.

Dentro dessa formação e baseado nos conceitos da época, Pimenta e Gonçalves (1990) evidenciam o fato de que as professoras esperavam um 'aluno ideal', por isto, cada vez mais o currículo de formação se distanciava da realidade existente nas escolas, impossibilitando o professor de ensinar e o aluno de adquirir o conhecimento mínimo. Este procedimento continuou em ação, mesmo depois da Lei de Diretrizes e Bases da Educação Nacional 


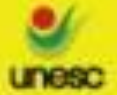

(4.024/61), que "não alterou significativamente o ensino normal. " A formação continua em dois ciclos, sendo agora eles "Escolas Normativas Ginasiais, com 4 anos de duração" e "Escolas Normais Colegiais, com 3 anos de duração. " O mercado de acesso foi expandido cada vez mais, portanto maior se deu o acesso para as classes médias. No entanto, o nível de evasão nas escolas encaminhou para uma nova Reforma do Ensino de $1^{\circ}$ e $2^{\circ}$ graus. Portanto, reforma-se a LDB para o $1^{\circ}$ e $2^{\circ}$ Graus (Lei 5.692/71), e o curso de Magistério passa a ser "Habilitação Especifica para o Magistério" em nível de $2^{\circ}$ grau, extinguindo as escolas, pouco a pouco antes existentes, tornando restrita a formação de professor no curso de Pedagogia. Neste momento, para Nóvoa (1992) a formação de professores foi marcada, nos anos 70 pelo período de debate de inclusão das grandes referencias teóricas, curriculares e metodológicas na grade de ensino e formação de professores, abandonando a prática de ensino sem embasamento.

Logo após, segundo Nóvoa (1992), nos anos 80 ocorreu a profissionalização dos professores. Que obteve uma grande importância para os docentes, mas que no fim acabou por marcar uma degradação e uma visão de desqualificação da profissão professor. A partir disto, nos anos 90 se deu início a prática de formação contínua para professores, que também foi um marco importante, mas que acabou desvalorizando a formação inicial e a profissionalização do professor. Neste momento, esta degradação da profissão professor se dá porque tanto a formação inicial, como a contínua, ocorre distinta da formação pessoal. Sendo assim, ao formar um docente, as instituições não consideram a bagagem que este já possui diante da vida, melhor dizendo, ao escolher essa profissão o adulto já tem conceitos e definições sobre a vida e formas de agir e muitas vezes esses conceitos existentes são ignorados para que se comece o ensino do zero. O que justifica, para Nóvoa (1992) o mal resultado que as formações continuadas obtêm, pois ela deve servir como um auxilio pessoal e conjunto para as instituições, mas acaba por resultar em uma formação individualista.

A partir dessas mudanças se dá início ao debate da proximidade entre teoria e prática, criando a importância de quebrar a dicotomia entre ambas. Segundo Libâneo,

[...] A profissão de professor, combina sistematicamente elementos teóricos com situações práticas reais. Por essa razão ao se pensar um currículo de formação, a ênfase na prática como identidade formadora aparece, à primeira vista, como exercício formativo para o futuro professor. (LIBÂNEO, 2001, p.94).

Saberes Pedagógicos, Criciúma, v. 3, nº1, janeiro/junho 2019.- Curso de Pedagogia- UNESC 


\section{SABERES PEDAGÓGICOS}

Revista do Curso de Graduaçāo de Pedagogia - Unesc

ISSN 2526-4559

Ou seja, dentro da formação e atuação do pedagogo teoria e prática são indissociáveis, tornando a formação de professores mais abrangente e completa diante a realidade existentes nas salas de aulas. Complementando isto, Moita (2000) diz que "ninguém se forma no vazio. Formar-se supõe troca, experiência, interações sociais, aprendizagens, um sem fim de relações. " (MOITA, 2000, p.115). Sendo assim, o processo de formação que ocorre com cada indivíduo, mesmo acontecendo da mesma forma, se transforma em cada pessoa, pois, são através das interações sociais, experiências, personalidades que se completa este processo. Portanto, único, mas não individual.

Neste momento é importante ressaltar a responsabilidade da universidade quanto a formação inicial e continuada dos professores e quanto a sua aproximação com as escolas. Segundo Medeiros (2010) para que o processo de formação continuada se desenvolva, é necessário que haja um conhecimento prévio sobre os professores que o realizaram, suas práticas, crenças, ideologias, enfim, para que se possa compreender que esses profissionais não chegam nessas formações vazios, e para que a partir disto seja possível envolver os professores no conteúdo e não somente que tenham presença buscando apenas o certificado. Portanto, Medeiros (2010) enfatiza que para o atual problema das formações continuadas não se pode responsabilizar total e somente os professores, pois são múltiplos os fatores que contribuem para essa má formação.

\section{METODOLOGIA, APRESENTAÇÃO E ANÁLISE DE DADOS}

Esse capítulo apresenta os recursos utilizado para o alcance dos dados, contendo a classificação da pesquisa, procedimentos técnicos e apresentação dos resultados.

A pesquisa de natureza qualitativa considera uma relação direta entre o objetivo e o pesquisador. Sendo assim, “[...] estabelecer uma série de correlações para, ao final, darmos nosso ponto de vista conclusivo." (OLIVEIRA, 2002, p.177). Nos permite uma expansiva leitura e envolvimento teórico para que depois o pesquisador conclua seus fatos.

O modelo de pesquisa exploratória busca a aproximação do problema com as hipóteses de pesquisa. Assim, explora o conhecimento e as experiências de quem já se

Saberes Pedagógicos, Criciúma, v. 3, nº1, janeiro/junho 2019.- Curso de Pedagogia- UNESC 

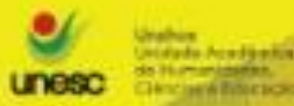

relaciona com o tema a ser estudado. Para isto Gil (1996, p.45) diz que "estas pesquisas têm como objetivo proporcionar maior familiaridade com o problema, com vistas a torná-lo mais explícito ou a construir hipóteses. "Esta pesquisa nomeou-se descritiva pois buscou conhecer, “[...] a descrição das características entre determinada população ou fenômeno ou, então, o estabelecimento de relações entre variáveis. " (GIL, 1996, p.46).

Neste caso, a pesquisa contou com a colaboração de sete professoras do primeiro ano do ensino fundamental, que atuam duas escolas da rede municipal do Extremo Norte do Rio Grande do Sul, no momento de hora atividade das professoras, buscando analisar se os professores do $1^{\circ}$ Ano do Ensino Fundamental reconhecem os diferentes níveis da escrita, segundo a psicogênese e fazem uso desse conhecimento, no processo inicial de alfabetização. A escolha das professoras ocorreu de forma aleatória, conforme a disponibilidade das mesmas. É válido lembrar que, numa dessas escolas escolhidas ocorreu uma rejeição pela parte da diretora, impossibilitando que a entrevista ocorresse naquele local.

Para uma melhor compreensão foi realizada uma coleta de dados por meio de uma pesquisa com roteiro, aplicado pessoalmente e que contou com perguntas abertas numa entrevista semiestruturada. A análise de dados ocorreu posteriormente, através de uma análise entre as respostas obtidas e o referencial teórico posto inicialmente.

\section{O docente e sua formação epistemológica}

De acordo com as professoras P.1, P.6 e P.7 o processo inicial da leitura e da escrita ocorre de maneira tradicional, ou seja, através do ensino do alfabeto e das famílias silábicas. Ainda segundo o relato da P.7, "estou trabalhando as famílias silábicas, e depois iremos para as silábicas complexas". A partir disto é possível identificar que o ensino para essas professoras ocorre de maneira tradicional. Neste momento me questiono sobre o processo de ensino que está ocorrendo dentro das salas de aulas dessas professoras, de que maneira ambas estão lidando com as diferentes crianças que se recebe nas escolas? Como que ocorre a formação continuada dessas professoras? Será que ainda consideram que as crianças são meras receptoras da aprendizagem da língua escrita? Com todos os estudos e pesquisas existentes atualmente ainda é possível esperar esse padrão de criança passiva, capaz apenas de reproduzir aquilo que a professora determina?

Saberes Pedagógicos, Criciúma, v. 3, nº1, janeiro/junho 2019.- Curso de Pedagogia- UNESC 

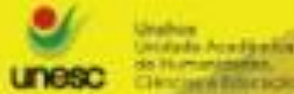

Por consequência trago os estudos de Ferreiro e Teberosky (1999), que refletem e discutem justamente o processo contrário aos relatos, das entrevistadas, quando se referem ao processo de ensino-aprendizagem da leitura e escrita, ou seja,

[...] no lugar de uma criança que espera passivamente o reforço externo de uma resposta produzida pouco menos que o acaso, aparece uma criança que [...] formula hipóteses, busca regularidades, coloca a prova suas antecipações e cria sua própria gramatica. [...] (FERREIRO, TEBEROSKY, 1999, p.24).

Sendo assim, quando as professoras entrevistadas dizem que realizam o processo de ensino e aprendizagem das crianças através do alfabeto e das famílias silábicas, diretamente essas professoras estão contrariando aquilo que se vem estudando por anos e que foi questionado e desconstruído por diferentes autores, até mesmo os já citados aqui. Essas professoras refletem um ensino egocêntrico, onde o professor é centro da sala de aula e dono de uma verdade absoluta, enquanto que os seus alunos são os seus seguidores. Desacreditando da capacidade dos mesmos de questionar e criar novas hipóteses sobre a escrita, ou seja, alunos passivos apenas receptores do conhecimento que a professora dispõe.

Da mesma forma a P.4 diz "costumo ler as letrinhas para os meus alunos, e conforme vou lendo também vou desenhando no quadro, para que eles consigam assimilar posteriormente". Ainda enfatizando um ensino tradicional, além de baseado no estudo das sílabas e fixação por meio de imagens. Também se espera que a criança pronuncie bem cada letra, para que assim seja capaz de escrever bem. O que é um marco do ensino tradicional, “noções tão importantes para o ensino tradicional como são as de 'falar bem' e possuir uma boa articulação. " (FERREIRO, TEBEROSKY, 1999, p.26). Para isto, eis o questionamento sobre como se pode definir o modo correto de pronunciar uma palavra, mediante as variações linguísticas existente dentro do Brasil? Ou ainda, como vamos exigir isso dos alunos, se segundo Soares (2005) nós não escrevemos como falamos e vice-versa. Neste momento é importante relembrar o que Ferreiro e Teberosky (1999) falam sobre o pré-conceito que a criança possui da linguagem escrita e falada. Ou seja, "não se pode achar que a criança não sabe nada sobre sua linguagem materna. Esperar que comece do zero." (FERREIRO, TEBEROSKY, 1999, p.27). A criança quando chega na escola não é vazia de conhecimento, portanto, o professor precisa considerar que aos 6 anos, a criança já possui, conceitos, formula hipóteses e tem opiniões sobre o processo de desenvolvimento da leitura e da escrita. Sabe-se

Saberes Pedagógicos, Criciúma, v. 3, nº1, janeiro/junho 2019.- Curso de Pedagogia- UNESC 


\section{SABERES PEDAGÓGICOS}

Revista do Curso de Graduaçāo de Pedagogia - Unesc

ISSN $2526-4559$

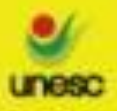

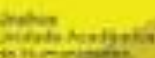

edinesc

que, dentro de uma sala de aula, não é possível esperar que as crianças não possuam qualquer conhecimento, ou que irão desenvolver a leitura e a escrita de acordo e no momento que a professora decidir ser o melhor. Ou seja, a prática que Braggio (1992, p.11) irá chamar, novamente, de "controle de aprendizagem", deste modo, somente a professora é capaz de decidir e saber qual o momento mais adequado para todas as crianças aprenderem determinada letra. Seguindo sempre a linha de raciocino de começar das mais fáceis para as mais difíceis. E considerando que todas as crianças passam pelo processo de desenvolvimento de leitura e escrita da mesma maneira e no mesmo instante.

Em contrapartida as demais professoras, P.2, P.3 e P.5 relataram que realizam o processo de alfabetização através dos nomes das crianças. Segundo a fala da P.3, "meus alunos têm nomes diversificados, então eu procuro ensinar eles a partir dos nomes próprios. ”. Essa prática está em conformidade com o que a psicogênese defende, que é a utilização do nome para auxiliar no processo de desenvolvimento da escrita, ou seja "[...] usar as identidades ou semelhanças sonoras entre as palavras para representar novas palavras [...]. ” (FERREIRO, TEBEROSKY, 1999, p. 223). Trazer o conhecido como intermediário para novas hipóteses de palavras, e de forma intencional utilizar um ensino que faça sentido para a criança.

Entretanto, ressalto que enquanto as demais professoras alegam "não seguir nenhuma linha pedagógica”, a P.2 ao ser questionada relata que se baseia num ensino tradicional. O que mais uma vez surpreende por ser uma entrevista atual, onde as bases teóricas já vão muito além dessa prática, e não se espera mais que um professor alfabetizador baseie seu ensino em métodos que diminuam a capacidade de desenvolvimento intelectual dos alunos, por explorar uma busca pela verdade absoluta.

A partir disto, as setes professoras foram questionadas quanto ao seu conhecimento sobre a teoria psicogenética de Emília Ferreiro. Somente as entrevistadas P.6 e P.7 disseram não conhecer, enquanto que todas as restantes afirmaram conhecer a teoria. Deste modo, comparando com seus processos de ensino relatados na entrevista reflito, se ambas conhecem a teoria psicogenética, porque não fazem uso? Será que para essas professoras o ensino baseado na família silábica ainda é suficiente para as crianças? Com base nos estudos apresentados e a entrevista realizada, observo que o ensino para essas professoras ainda é

Saberes Pedagógicos, Criciúma, v. 3, nº1, janeiro/junho 2019.- Curso de Pedagogia- UNESC 


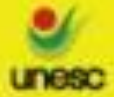

realizado a partir daquilo que a professora acredita ser o ideal, não necessariamente importando-se diretamente com alguma base teórica. Neste caso, ao considerar que a criança desenvolve a escrita a partir de repetições para decorar conteúdo, onde fica o conhecimento sobre a leitura e a escrita como um processo de construção de conhecimento? Portanto, como se espera que se conclua o processo de ensino e aprendizagem das crianças dessas escolas?

A partir disto, reflito quanto ao processo de formação das professoras entrevistadas, segundo o que ambas relataram na entrevista, sobre suas ações quanto ao processo de alfabetização de seus alunos. Partindo do princípio de que todas têm o conhecimento e a prática, não seria o ideal essas professoras já terem refletido sobre o que estão desenvolvendo em sua prática pedagógica atualmente? A partir dos perfis das entrevistadas, percebe-se que, provavelmente, ambas foram alfabetizadas com um método tradicional, partindo de um ensino sem sentido, apenas buscando a "resposta correta". Então, neste momento, depois de todo conhecimento adquirido em sua formação, ainda é válido aceitar o mesmo meio de ensino nas escolas? Segundo Nóvoa (1992) e Libâneo (2001) a teoria e a prática são indissociáveis, assim, como admitir que essas professoras ignorem os conhecimentos contemporâneos de alfabetização e partam do princípio egocêntrico de que "o professor é o dono da sala e faz o que quer lá dentro".

\section{O exercício epistemológico da docência}

Posteriormente as professoras P.1, P.2, P.3 e P.6 disseram que seguem livros didáticos para o planejamento de suas aulas. Neste caso, vale ressaltar que a P.1 particularmente, relatou o seguinte, "prefiro uns mais antigos, dos novos não uso." Portanto, conforme Smolka $(1999$, p. 17) "[...] as atividades de leitura e escrita, baseadas no livro didático, são totalmente desprovidas de sentido, e totalmente alheias ao funcionamento da língua, contrastando violentamente com as condições de leitura e escrita das sociedades letradas [...]". Portanto, os livros didáticos existentes nas escolas são inadequados as capacidades de leitura e escrita que as crianças da sociedade atual possuem, ou seja, já não se pode mais esperar que os livros didáticos por si só sejam suficientes dentro de uma sala de aula. Considerando ainda mais que ele é um meio de auxílio para o professor e não a base de ensino, já não se pode mais admitir 


\section{SABERES PEDAGÓGICOS}

Revista do Curso de Graduaçāo de Pedagogia - Unesc

ISSN $2526-4559$

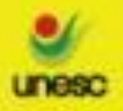

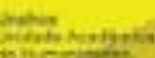

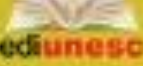

que o processo de ensino da leitura e da escrita ocorra somente através dos livros didáticos. É preciso ultrapassá-los.

Em contrapartida as entrevistadas P.4, P.5 e P.7 ressaltam não utilizar o livro didático, por motivos divergentes. Logo a P.4 diz, "não uso porque não tem para todos, então eu prefiro pegar coisas da internet para me basear". Refletindo esta prática relembro que, basta uma pequena pesquisa na internet para percebermos que, na maioria dos casos, as atividades propostas ali são completamente tradicionais e ultrapassadas, ou seja conteúdos prontos, refletindo mais uma vez um ensino baseado na reprodução mecanicista da língua. Espera-se neste caso, que a criança a partir desta repetição constante, consiga alcançar os objetivos do professor, sem qualquer interesse quanto a real apreensão do conhecimento. Em contraste com este processo de ensino, trago a fala da P.5 dizendo que "não uso, porque acho eles ainda muito óbvios para as crianças que eu recebo na sala". Ou seja, a P.5 pode apresentar indícios de um ensino diferenciado da língua, das demais professoras entrevistadas. Aponta por uma certa preocupação com o desenvolvimento linguístico das crianças, conforme proposto nos Parâmetros Curriculares da Língua Portuguesa. Abandonando, portanto, um ensino tradicional e desta forma, representando o que Smolka (1999) diz sobre o uso do livro didático, ou seja, um ensino dispensável para as crianças que chegam nas salas de aula atualmente.

Posteriormente as entrevistadas P.1, P.3 e P.5 disseram que procuram identificar os diferentes níveis psicogenéticos no planejamento de suas aulas, mesmo anteriormente as P.1 e P.3 terem dito que fazem uso do livro didático para o planejamento de suas aulas. Portanto, neste caso, se fez necessário observar quais são os meios utilizados pelas professoras para identificar os níveis de alfabetização de seus alunos. Logo, a P.1 falou que utiliza o ditado doce para fazer este diagnóstico, ou seja, "colo um doce no quadro, e se a criança acertar a palavra ditada, então ela ganha o doce. "Realizando, portanto, um ensino baseado em recompensa, ou seja, estimulo e resposta. Que busca nada mais do que uma reprodução mecanizada de uma memorização anterior, para em seguida premiar quem consegue atingir seus objetivos. Ou seja, o que está em destaque, para a criança é a recompensa, aquilo que ela vai ganhar caso consiga realizar o que a professora deseja. O que contradiz aquilo que a psicogênese defende, que é a utilização do ditado sim, mas não desta forma e muito menos com este objetivo, mas uma prática de estudo da língua em que a criança "erre" para poder

Saberes Pedagógicos, Criciúma, v. 3, nº1, janeiro/junho 2019.- Curso de Pedagogia- UNESC 

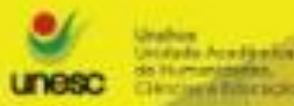

unese

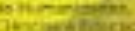

acertar, formule hipóteses sobre a construção de novas escritas. Em contrapartida, neste momento, a P.3 relata "gosto muito de usar o ditado em sala de aula, para depois conseguir saber o nível da escrita de cada um. " Ou seja, possui indícios do uso da teoria psicogenética, através do ditado que como dito anteriormente, é um meio para perceber o nível de escrita de cada criança, e de auxiliar ambas a perceberem as diferenças existentes entre a sua lógica de escrita e a lógica de escrita de um adulto, que convencionalmente é considerado a lógica correta. Em contraste com essa linha de raciocínio, as P.2, P.4 e P.6 disseram que não identificam os níveis de escrita nas suas aulas ou planejamentos, mesmo anteriormente afirmando conhecer o estudo da psicogênese.

Logo após, todas as sete professoras disseram que utilizam o ditado como meio de instrumento avaliativo para a verificação do desenvolvimento da leitura e da escrita das crianças. Entretanto, esse ditado ocorre de maneiras diversificadas, para as P.1, P.2, P.4, P.6 e P.7, o ditado ocorre a partir das letras, palavras e sílabas que a turma já conhece, ou seja, é apenas mais uma reprodução memorizada daquilo que elas já trabalharam anteriormente. E também, ressaltando mais uma vez, um ensino baseado nas tradicionais famílias silábicas. Enquanto que as P.3 e P.5 relatam que utilizam o ditado com as palavras já conhecidas, mas também com palavras novas, "procuro deixar eles escreverem da maneira deles, depois eles leem para mim, apontando a palavra", relata a P.3. Neste caso, evidencia o uso do ditado para uma identificação quanto ao nível de escrita de cada criança, ou seja, as professoras entrevistadas possuem indícios quanto ao uso da teoria psicogenética de Emília Ferreiro, considerando que o ditado para a mesma, é justamente o meio importante para o processo de identificação dos níveis psicogenéticos de cada criança.

Finalizando a entrevista as P.1 e P.3 disseram que fazem atividades diferenciadas quando necessário, mais precisamente "para aqueles que não conseguiram aprender ainda e para os que são o "problema" da sala. " Ou ainda, conforme relataram as P.2 e P.7, "acompanham na classe, de perto, para explicar individualmente os atrasados". Segundo Smolka (1999, p.39) "essas conclusões e suposições, que na realidade se caracterizam como pressuposições, transformam-se em preconceitos. E é isso que tem permeado, implicitamente as relações de ensino, na escola. " Ou seja, a criança muitas vezes tem o desejo quanto ao desenvolvimento da escrita e da leitura, no entanto ele é substituído pelas professoras pelo

Saberes Pedagógicos, Criciúma, v. 3, nº1, janeiro/junho 2019.- Curso de Pedagogia- UNESC 

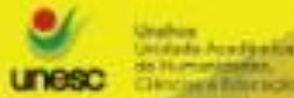

preconceito sobre os alunos que apenas se encontram em um nível de desenvolvimento diferenciado, mas que em sua grande maioria acabam por ser tachados de "fracassados ou incapazes". Entretanto, Ferreiro e Teberosky (1999) discutem justamente o esforço que cada criança realiza para desenvolver o processo de ensino da leitura e da escrita, esforço que as autoras definem como um "conflito cognitivo", evidenciando a importância do erro para que ocorra uma superação quanto aos seus próprios conflitos para que a criança consiga desenvolver diferentes hipóteses de escrita. As entrevistadas P.4, P.5 e P.6 disseram que "procuram fazer mais atividades sobre aquele assunto que no geral apareceu mais dificuldade", apesar das três afirmarem que "cada um tem o seu tempo para aprender".

Neste momento, questiono-me quanto a formação dessas professoras? Como que nos dias de hoje as professoras, entrevistadas, realizam esse ensino baseado em métodos visivelmente ultrapassados? Onde fica a base teórica dessas professoras? Existem atualmente tantas pesquisas e estudos sobre o processo de ensino de leitura e escrita, que identificam diversas metodologias para desenvolver o processo de ensino e aprendizagem na alfabetização, como que essas professoras ignoram este conhecimento, que ambas tiveram durante sua formação inicial? E também, será que ainda cabe ao professor decidir o que e como fazer dentro de uma sala de aula, a partir do que é melhor para ele?

Existem bases teóricas, que fundamentam a favor de um ensino construtivista, reflexivo sobre a língua escrita, um ensino que considera a criança em processo de alfabetização, ativa, que pensa sobre como se escreve as palavras, que erra para depois acertar. Então, como que essas professoras ignoram todo esse conhecimento, para fazer o que querem dentro de uma sala de aula? Portanto, infelizmente, a partir dessa pesquisa, observei que o ensino existente nas escolas em que foi realizada a pesquisa ainda deixa a desejar, pois a prática dos professores são muito precárias quando se trata de domínio de conteúdo, base teórica, incentivo a uma educação construtivista, sendo portanto um ensino fragmentado, baseado em uma escrita mecanizada e sem reflexão sobre o processo de aprendizagem, o que irá refletir futuramente nas dificuldades encontradas nas escolas e universidades, quando adultos e profissionais assumidos, no que se refere a leitura e escrita.

\section{CONCLUSÃO}

Saberes Pedagógicos, Criciúma, v. 3, nº1, janeiro/junho 2019.- Curso de Pedagogia- UNESC 
O presente artigo me proporcionou uma ampla reflexão quanto a metodologia de ensino que ainda está ocorrendo nas salas de aulas e também uma surpresa quanto aos relatos das professoras entrevistadas. Pois esperava-se algumas respostas diferentes e principalmente, mais atualizadas, entretanto, não ocorreu.

Segundo as entrevistas realizadas, foi possível concluir que os professores entrevistados não conhecem o ensino psicogenético de Emília Ferreiro. Destaca-se, no entanto, uma professora que apresenta indícios de um ensino construtivista e por diversas vezes relata ações relacionadas a psicogênese, mas ao mesmo tempo insiste em basear seu planejamento nos livros didáticos. Neste caso, percebo que é uma realidade fortíssima para as professoras entrevistadas, essa dependência quanto a utilização de livros didáticos para a elaboração e execução de seus planejamentos, automaticamente, um ensino tradicional e supérfluo para as crianças em fase de alfabetização.

A partir dos estudos e da pesquisa realizada, reflito que o ensino existente nestas escolas atualmente, ainda deixa a desejar quando se trata de enxergar o aluno como um Ser pensante e ativo, que é capaz de produzir e pensar sobre o que lhe está sendo apresentado. Pois, como foi dito diversas vezes, hoje não se tem mais aquela criança passiva, que apenas concede e repete aquilo que o professor ensina e, portanto, não se pode mais ter esse professor que espera um aluno padronizado, que aprende e desenvolve igualmente, todas as situações apresentadas. Claro que, muitas vezes, as professoras possuem o conhecimento, cursos, formações continuadas, entretanto não possuem estímulos e reconhecimento, pois a situação da educação atual também é um reflexo da importância que a educação está recebendo atualmente. Muito se fala em quantidade, seja de instituições, alunos, formações, mas e quanto à qualidade? Quem está preocupado em observar se essas instituições e as formações fornecidas, estão recebendo o devido apoio que precisam?

Quando procurei realizar a pesquisa, tinha como objetivo observar como as professoras buscam identificar esses diferentes níveis de ensino num processo inicial de alfabetização, no entanto durante o processo de pesquisa e análise observei que é necessário ir além, pois as práticas que estão sendo desenvolvidas dentro das salas de aulas já não são aceitáveis há muito tempo. Foram realizados estudos que comprovassem que a decoreba, o 

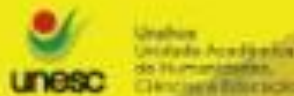

unesc

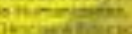

estimulo, associação com imagens, não são métodos/meios que auxiliem no processo de ensino da língua. A criança precisa desenvolver o conhecimento relacionado com o mundo, com as suas realidades, de acordo com o meio em que essa criança se encontra, logo, não é possível realizar esse processo da mesma maneira para todas, pois cada uma possui realidades e meios de compreensão diferente em relação a leitura e escrita.

Portanto, a partir dos estudos realizados durante o Curso de Pedagogia e principalmente as leituras para a realização do artigo, concluo que o processo inicial de alfabetização das crianças precisa ir muito além daquilo que as professoras acreditam ser o ideal, pois não existe fórmula pronta para ensinar, não há um meio que vá dar conta de tudo e de todos dentro de uma sala de aula, onde encontram-se diversas realidades e diferentes níveis de desenvolvimento. Logo as crianças desenvolvem o processo de aprendizagem da leitura de escrita de maneiras diversificadas.

Concluo esta pesquisa realizada constatando que o ensino existente atualmente sofre grandes consequências por conta da má formação que os professores recebem durante sua formação inicial, por falta de estímulos e investimentos na qualidade de ensino, e provavelmente por outros diversos motivos que deveriam ser estudados com mais frequência, para que esse problema, que futuramente terá grandes consequências, seja resolvido rapidamente.

\section{REFERÊNCIAS}

BRAGGIO, Silvia Lucia B. Leitura e alfabetização: da concepção mecanicista à sociopsicolinguística. Porto Alegre: Artes Médicas, 1992. 102p.

FERREIRO, Emília; TEBEROSKY, Ana; MARTINS, Cláudio. Psicogênese da língua escrita. Porto Alegre: Artmed, 1999. 300 p.

GIL, Antônio Carlos. Como elaborar projetos de pesquisa. 3.ed. São Paulo: Atlas, 1996. $159 \mathrm{p}$.

GONTIJO, Cláudia Maria Mendes. Alfabetização: políticas mundiais e movimentos nacionais. Campinas, SP: Autores Associados, 2014. 145 p. LIBÂNEO, José Carlos. Adeus professor, adeus professora? novas exigências educacionais e profissão docente. 5.ed. São Paulo: Cortez, 2001. 104 p. 
MOITA, Maria da Conceição. Percursos de formação e de trans-formação. NÓVOA, António. (Org.). Vidas de professores. 2.ed. Portugal: Porto Editora, 2000. 215 p.

MORTATTI, Maria do Rosário Longo. Os sentidos da alfabetização. São Paulo: Editora UNESP, 2000. 372 p.

NÓVOA, António. Formação de professores e profissão docente. In: NÓVOA, António (Org.). Os professores e a sua formação. Portugal: Dom Quixote, 1992. p. 15-33.

OLIVEIRA, Silvio Luiz de. Tratado de metodologia científica. São Paulo: Pioneira, 2002. 320p.

PIMENTA, Selma Garrido; GONÇALVES, Carlos Luiz. Revendo o Ensino de $2^{\mathbf{0}}$ Grau: propondo a formação de professores. São Paulo: Cortez, 1990. 159 p.

SMOLKA, Ana Luiza Bustamante. A criança na fase inicial da escrita: a alfabetização como processo discursivo. 8.ed. São Paulo: Editora da Universidade Estadual de Campinas, 1999. 135p.

SOARES, Magda. Alfabetização e letramento. 3.ed. São Paulo: Contexto, 2005. 123 p. 